\title{
Judicial Independence: European Standards, ECtHR Criteria and the Reshuffling Plan of the Judiciary Bodies in Poland
}

\author{
By Matteo Mastracci ${ }^{*}$
}

In Poland, after the Parliamentary election of 2015, the executive propelled a series of interlock reforms of the judicial bodies. In the first place, the way forward was marked by a compound diatribe concerning the Constitutional Tribunal, the essence of the dispute was about the mandate's legitimacy of three sitting judges after the Court's reinterpretation of the K 34/15 ruling that ended up on 2 December by the election of five new judges appointed ex novo by the ruling party. Afterwards, the attention shifted towards the rethinking of the National Council of Judiciary (KRS), asserting, firstly, the unconstitutionality of its statute and, subsequently, planning a new method of appointment for the judicial members. Ultimately, the spotlight turned in the direction of the Supreme Courts judges where the most spectacular sweep was the provision aimed at lowering the retirement age for the sitting judges on a scheme similar to the proposal made by the Hungarian government in 2011 where raised their voices respectively, the Hungarian Constitutional Court, the European Court of Justice and the European Court of Human Rights, where the judicial independence standard played a minor role on their reasoning.

Keywords: Judicial Independence; European standards; European Court of Human Rights; Poland; Law and Justice.

\section{Introduction}

The independence of the judicial branch is a foundational value for proper functioning of a society founded upon the rule of law $^{1}$ as well as of a society shaped by a constitutional liberal democratic order.

The latter, following the French tradition of Montesquieu ${ }^{2}$, is based on the core principle of the "separation of powers", which in order to prevent a potential monopoly of power or the emergence of authoritarianism forms, requires the distinction and, therefore, the independence, of the three traditional State's actors, legislative, executive and judiciary branch.

The essential role that separation of powers should play within the liberal democratic order is expressed by the incorporation of the principle itself into many national legal systems at Constitutional level and, amongst the many European legal orders, Article 173 of the Polish Constitution which states as

\footnotetext{
*PhD Researcher, Koç University, Rumelifeneri Mahallesi, Sarıyer Rumeli Feneri Yolu, Sarıyer, Istanbul, Turkey. E-mail: mmastracci18@ku.edu.tr.

${ }^{1}$ See e.g. introduction of International Association of Judges (1999).

${ }^{2}$ Which as clearly noted by Shetreet (2015).
} 
follow "The courts and tribunals shall constitute a separate power and shall be independent of other branches of power" ${ }^{3}$.

Furthermore, it is worth noting that all the main rules of law's components, namely legality, legal certainty, prohibition of arbitrariness and respect for human rights ${ }^{4}$ are mainly influenced for their proper functioning by the further and additional requirement of access to justice mechanisms with regard to which the concept of judiciary independence entails a constitutive prerequisite; in this significance the Judicial independence is "a pre-requisite of the rule of law system",

At international level, the Special Rapporteur of the Commission on Human Rights took a further step when it was clarified that the judicial independence is "part of the general principles of law recognised by civilised nations" 6 and, for that reason, "the independence of the judiciary shall be guaranteed by the State and enshrined in the Constitution or the law of the Country. It is the duty of all governments or other institutions to respect and observe the independence of the judiciary" 7 .

However, independence does not mean that the judicial power should be non accountable, because if it were so, the independence would degenerate into irresponsibility $^{8}$; therefore, independence should be interpreted not as a value or an end in itself, but as an "instrumental value", a means for the appropriate safeguard of other fundamental values and above and beyond the rule of law and the liberal democratic order of the contemporary European constitutional traditions.

\section{European Standards}

At the European level, several legal instruments concur to form a more complete European legal scenario, many of which are expressed in the form of soft law tools; however, it should be noted the primary importance of the fair trial principle enshrined in Article 6 of the European Convention on Human Rights ${ }^{10}$ and Article 47 of the EU Charter on Fundamental Rights is entitled "Right to an effective remedy and to a fair trial"11.

The other functional legal instruments include the Council of Europe Recommendation on Judges: Independence, efficiency and responsibilities ${ }^{12}$, the Council of Europe Recommendation on the Independence, efficiency and

\footnotetext{
${ }^{3}$ Constitution of the Republic of Poland, 1997, Art. 173.

${ }^{4}$ See European Commission (2014).

${ }^{5}$ The Judicial Integrity Group (JIG) (2002) at Val. 1, Independence.

${ }^{6}$ United Nations (1995) at par. 34.

${ }^{7}$ United Nations (1985).

${ }^{8}$ See Storme (2015).

${ }^{9}$ Cappelletti (1983).

${ }^{10}$ Council of Europe (1950) at Article 6.

${ }^{11}$ European Union (2012) at Article 47.

${ }^{12}$ Council of Europe (2010).
} 
role of judges ${ }^{13}$ and the subsequent Opinion No. 1 of the Consultative Council of European Judges $^{14}$, the European Charter on the statute for judges ${ }^{15}$, the Magna Carta of Judges $^{16}$, the Judges' Charter in Europe ${ }^{17}$, the Kyiv Recommendations on Judicial Independence in Eastern Europe, South Caucasus and Central Asia ${ }^{18}$, the Venice Commission's Recommendations ${ }^{19}$, the Opinions of $\mathrm{CCJE}^{20}$ and the Reports of $\mathrm{ENCJ}^{21}$.

Although the legal scenario could be interpreted, prima facie, rather labyrinthine and somewhat twisted, nonetheless, some common principle emerged on the ground and, as a result, they form altogether a shared European perception around the core meaning of judicial independence that could be labelled as the "European standards" framework.

\section{Council of Europe}

The standards set by the Council of Europe, the most authoritative institution in the European panorama, firstly, primarily dealt with the appropriate allocation of the principle of Judicial Independence within the national legal frameworks; as a matter of fact, the principle itself should be enshrined in the "constitution or at the highest legal level in member states",2 or "set out in internal norms at the highest level"23 or "by inserting specific provisions in the constitution or other legislation" 24 .

The 1994 Recommendation showed from the very beginning its fear from an undue pressure by the other State powers, stating that "The executive and legislative powers should ensure that judges are independent and that steps are not taken which could endanger the independence of judges" 25 and, as a result, the judicial body should be vested with the full guarantee of the principle of irremovability, indeed "Judges, whether appointed or elected, shall have guaranteed tenure until a mandatory retirement age or the expiry of their term of office" .

It is interesting to note that the 2010 Recommendation stepped into the core of the matter establishing a twofold nature of the independence, external and internal,

\footnotetext{
${ }^{13}$ Council of Europe (1994).

${ }^{14}$ Consultative Council of European Judges (2001).

${ }^{15}$ Council of Europe (1998).

${ }^{16}$ Consultative Council of European Judges (2010).

${ }^{17}$ European Association of Judges (1997).

${ }^{18}$ OSCE (2010).

${ }^{19}$ Venice Commission (2010); Venice Commission (2007).

${ }^{20}$ Consultative Council of European Judges (2001), Consultative Council of European Judges (2003), Consultative Council of European Judges (2005), Consultative Council of European Judges (2007), Consultative Council of European Judges (2014), Consultative Council of European Judges (2015).

${ }^{21}$ European Network of Council for the Judiciary (2010-2011).

${ }^{22}$ Council of Europe (2010) at Chapter I, General Aspects.

${ }^{23}$ Council of Europe (1998) at Principle 1.2.

${ }^{24}$ Council of Europe (1994) at Principle I.2.a.

${ }^{25}$ Council of Europe (1994) at Principle I.2.b.

${ }^{26}$ Council of Europe (1994) at Principle I.3.
} 
where the external influence, more sensitive than the internal, is at the heart of the concept of judicial independence and, as a result it seems to have a broader scope $^{27}$.

Furthermore, in the European Charter of the Statute of Judges ${ }^{28}$, which its legal effects are non mandatory but only serve as guidelines in order to propel national legislation accordingly, it is worth noting the suggestion to appoint an independent authority composed by the judicial body members with supervisory and authoritative functions within the national legal order, "the statute envisages the intervention of an authority independent of the executive and legislative powers" $" 29$ in dealing with cases involving all the issue concerning the judges' careers "of every decision affecting the selection, recruitment, appointment, career progress or termination of office".

In doing so, the Charter envisaged a general method of appointing members within the independent authority and the composition of the body, more precisely, "at least one half of those who sit are judges elected by their peers following methods guaranteeing the widest representation of the judiciary" "30.

\section{Venice Commission}

The role played by the Venice Commission on the judicial independence matter is, likewise, particularly significant and it converges in the form of general recommendations: the 2007 Report on Judicial Appointments, the 2010 Report on the Independence of the Judicial System ${ }^{31}$ and the 2008 European Standards on the Independence of the Judiciary, Systematic Overview ${ }^{32}$.

The 2007 Report dawned its introduction around a concern (rectius challenge) for the so-called newly established democracies, clearly referring to the forthcoming enlargement of two CEE countries (namely, the accession of Bulgaria and Romania), where concerns related to the independence and political impartiality of the judiciary still persist and, referring to the political involvement in the appointment procedure that could endanger the neutrality of the judiciary.

Afterwards, it called attention in its conclusion on the existence of a crucial criticism, when it stated that, however, no single non-political "model" of appointment system exists, which could ideally comply with the principle of the separation of powers and secure full independence of the judiciary ${ }^{33}$.

As for the suggested system of judicial appointments, after prior invoking the Council of Europe's Recommendation (94) 12, on the need of "objective criteria, merit, qualification, integrity" 34 ; the Report suggested the way forward for the approaching Member States when disclosed that:

\footnotetext{
${ }^{27}$ Council of Europe (2010)12.

${ }^{28}$ Consultative Council of European Judges (2001).

${ }^{29}$ Consultative Council of European Judges (2001) at Principle 1.3.

${ }^{30}$ Ibid.

${ }^{31}$ See European Association of Judges (1997).

${ }^{32}$ Venice Commission (2008).

${ }^{33}$ Ibid. par. 44.

${ }^{34}$ See Council of Europe (1994) at Principle I, 1.c.
} 
"New democracies, however, did not yet have a chance to develop these traditions, which can prevent abuse. Therefore, at least in new democracies explicit constitutional provisions are needed as a safeguard to prevent political abuse by other state powers in the appointment of judges." ${ }^{, 35}$

In conclusion, the report coped with the key argument of the need to set up of a Judicial Council and, even though "the mere existence of a high judicial council cannot automatically exclude political considerations in the appointment process" appointment and promotion of judges and on disciplinary measures against them,"37.

Moreover, as regards the suggested composition, the report drawn a double standard, first of all "a substantial element or a majority of the members of the Judicial Council should be elected by the Judiciary itself", then, it stressed out the necessity to provide within the Council a "democratic legitimacy" component and, as a result,

"In a system guided by democratic principles, it seems reasonable that the Council of Justice should be linked to the representation of the will of the people, as expressed by Parliament $" 38$.

The second notable legal tool provided by the Venice Commission is the 2010 Report on the Independence of the Judicial System ${ }^{39}$.

At the outset, the report emphasised the double nature, objective and subjective, of the independence which is, consequently, not an end in itself but it should ensure that judges fulfil their essential role of "guardians of the rights and freedoms of the people" ${ }^{\text {, }}$, while underlining at the same time the internal and external components,

"External independence shields the judge from influence by other state powers and is an essential element of the rule of law. Internal independence ensures that a judge takes decisions only on the basis of the Constitution and laws and not on the basis of instructions given by higher ranking judges ${ }^{41}$;",

then, it affirmed that the most authoritative texts on the subject matter are the 1994 Recommendation of the Council of Europe ${ }^{42}$ and the Consultative Council of European Judges' Opinion No. $1^{43}$.

\footnotetext{
${ }^{35}$ Council of Europe (1994) par. 6.

${ }^{36}$ Council of Europe (1994) par 23.

${ }^{37}$ Council of Europe (1994) par. 25.

${ }^{38}$ Venice Commission (1998).

${ }^{39}$ Venice Commission (2010).

${ }^{40}$ Venice Commission (2010) par. 6.

${ }^{41}$ Council of Europe (1994) par. 56.

${ }^{42}$ See Council of Europe (1994) at Principle I.2.a.

${ }^{43}$ Consultative Council of European Judges (2001).
} 
Afterwards, the report focused its attention on the national level that should incorporate the principle, "The independence should be guaranteed pursuant to the provisions of the Convention and constitutional principles by inserting specific provisions in the Constitutions or other legislation" 44 or, even more precisely, "The fundamental principles of the statute for judges are set out in internal norms at highest level, and its rules in norms at least at the legislative level" 45 , therefore, Venice Commission draw a conclusion that "The basic principles ensuring independence should be set out in the Constitution or equivalent text"46.

With regard to the criteria in order to recruiting the judicial personnel, those according to the Council of Europe's standards should be "based on objective criteria, and selection based on merit, regard to qualifications, integrity, ability and efficiency" 47 and, as a result, Venice Commission came to the conclusion that "All decisions on appointment and the professional career based on merit, applying objective criteria within the framework of the law is indisputable" 48 .

In addition, the report set foot into the central question of the establishment of an independent body or authority in order to supervise the overall judicial independence's system and, for that scope, stated that "appropriate method that an independent judicial council have decisive influence on decisions on appointment and career, there is no single model which applies to all countries, while respecting this variety of legal systems, states should consider the establishment of an independent body and in all cases should have a pluralistic composition with a substantial part, if not the majority, of members being judges, with the exception of ex-officio members these judges should be elected or appointed by their peers" 49 .

Subsequently, pertaining to the tenure, length of mandate, of the judicial office and to what extent the guarantees should be recognised to the judges, the report citing, firstly, the Council of Europe which expressed that ended up that

"strongly recommends that ordinary judges be appointed permanently till retirement age [...] the principle of irremovability should have a Constitutional basis, transfers against the will of the judge may be permissible only in exceptional cases 50 ,"

On a final note, the report addressed the rules on the proper allocation of judicial cases within the judiciary bodies, showing, firstly, a criticism, "In many countries court presidents exercise a strong influence by allocating cases to individual judges" by drawing of lots or a system for automatic distribution according to alphabetic

\footnotetext{
${ }^{44}$ Council of Europe (1994) at Principle I.2.a., Principle I.2.a.

${ }^{45}$ Consultative Council of European Judges (2001) at par. 16.

${ }^{46}$ Venice Commission (2010). par. 22.

${ }^{47}$ Council of Europe (1994) at Principle I.2.a. and I.2.f., Principle I.1.c.,par. 45.

${ }^{48}$ Venice Commission (2010) par. 27.

${ }^{49}$ Venice Commission (2010) par. 32.

${ }^{50}$ Venice Commission (2010) par. 43.

${ }^{51}$ Venice Commission (2010) par. 74.
} 
order of some similar system,, 52 , or, similarly, "should follow objective criteria",53, therefore, as a consequence, Venice Commission drawn its conclusion by the following statement "based to the maximum extent on objective and transparent criteria established in advance by law or special regulations on the basis of the law, exceptions should be motivated" 54 .

Finally, the Venice Commission further clarified its standards in the 2008 Recommendation on the European Standards on the Independence of the Judiciary, Systematic Overview ${ }^{55}$, confirming once again that the principle of judicial independence should be enclosed in Constitutional provisions ${ }^{56}$, the decisions concerning the judicial careers should be based on objective criteria ${ }^{57}$, the judicial council should have a decisive role in judicial appointments in order to safeguard to judicial independence and its composition should reflect a substantial element or a majority of judicial members ${ }^{58}$, the principle of judicial irremovability is a cornerstone in order to prevent democratic backlashes that could erode the judicial independence.

\section{CCJE Opinions and the Magna Carta of Judges}

The Consultative Council of European Judges in 2001 with the Opinion No. $1^{59}$ clarified that judicial independence is a pre-requisite of the rule of law and a fundamental guarantee of a fair trial; furthermore, the independence is not a privilege of the judges themselves, but in the interests of the rule of law and of those seeking and expecting justice ${ }^{60}$, therefore, the principle should be guaranteed at the highest level and, preferably at constitutional level or among the fundamental principles by those countries with no written text ${ }^{61}$. Moreover, the judges' mandate should be guaranteed until a mandatory retirement age or the expiry of a fixed term of office and irremovability of judges should be enshrined at the highest internal level ${ }^{62}$.

Then, the Opinion dealt with the standards concerning the basis of appointment or promotion confirming that all the decisions about the judges career should be based on objective criteria, with the aim of ensuring that the selection and career are based on merit, having regard to qualifications, integrity, ability and

\footnotetext{
${ }^{52}$ See Council of Europe (1994) at Principle I.2.a. and I.2.f.

${ }^{53}$ Venice Commission (2002) at par. 70.7.

${ }^{54}$ Venice Commission (2002) at par. 81.

${ }^{55}$ Venice Commission (2008).

${ }^{56}$ Venice Commission (2008) at par. 2. Cfr. Council of Europe (1994) at Principle I.2.a. and Consultative (2001) at 16.

${ }^{57}$ Venice Commission (2008) at par. 3. Cfr. Council of Europe (1994) at Principle I.2.a. and Consultative (2001) at 16.

${ }^{58}$ Venice Commission (2008) at par. 3

${ }^{59}$ Consultative Council of European Judges (2001).

${ }^{60}$ Consultative Council of European Judges (2001) at $\S 10$; see also Consultative Council of European Judges (2015).

${ }^{61}$ Consultative Council of European Judges (2001) at $\S 14$.

${ }^{62}$ Consultative Council of European Judges (2001) at $\S 57$ and $\S 60$; Consultative Council of European Judges (2003).
} 
efficiency ${ }^{63}$; furthermore, these objective standards are required not merely to exclude political influence, but for other reasons, such as the risk of favouritism, conservatism and cronyism (or "cloning"), which exist if appointments are made in an unstructured way or on the basis of personal recommendations ${ }^{64}$.

Another crucial standard is the need to establishing an independent authority, namely the Council for the Judiciary, in order to supervise the whole process of the judicial appointments, in this meaning the Opinion declared that in the former communist countries, the need is highly pressing and, particularly, for those countries which do not have other long-entrenched and democratically proved systems ${ }^{65}$.

In 2010, the Consultative Council of European Judges adopted the Magna Carta of Judges ${ }^{66}$ which in the introductory part affirmed that the independence is intended as a fundamental aspect of the general principle known as the rule of law, rule of law and independence are intimately connected to each other, "the judiciary is one of the three powers of any democratic state. Its mission is to guarantee the very existence of the Rule of Law"

In the text, the most interesting part, is the one about an independent judicial body that should be established in order

"to ensure independence of judges, each State shall create a Council for the Judiciary or another specific body, itself independent from legislative and executive powers, endowed with broad competences for all questions concerning their status as well as the organisation, the functioning and the image of judicial institutions. The Council shall be composed either of judges exclusively or of a substantial majority of judges elected by their peers $^{68}$."

\section{Judges' Charter}

Another pertinent legal text is the Judges' Charter in Europe, adopted by the European Association of Judges in 1997, which in its introductory remarks gives emphasis to "the independence of the judiciary as one of the foundations of the rule of law",69.

Additionally, when the Charter set foot in the very essence of the Judicial Independence's meaning, it seems the legal text more concerned about the possible erosion of the fundamental principle of "separation of powers" as well as the need to protect the "rule of law" when it observed that "The process of European integration has brought about an expansion of legislative and executive power" and "a genuine separation of powers is indispensable for the proper

\footnotetext{
${ }^{63}$ Consultative Council of European Judges (2001) at 25.

${ }^{64}$ Consultative Council of European Judges (2001) at 24.

${ }^{65}$ Consultative Council of European Judges (2001) at $\S 45$, see also Consultative Council of European Judges (2007).

${ }^{66}$ Consultative Council of European Judges (2010).

${ }^{67}$ Consultative Council of European Judges (2010) at Art. 1.

${ }^{68}$ Consultative Council of European Judges (2010) at Art. 13.

${ }^{69}$ European Association of Judges (1997).
} 
functioning of any State that respects the rule of law" "70; this is why, later on, its primary focus was mainly towards the external dimension of judicial independence.

Independence seen as an unassailable ${ }^{71}$ value to be protected at national and international level, where the judicial members are accountable only to the law and without paying no need to political parties or pressure groups ${ }^{72}$ and, especially, in the appointing procedure no outside influence and no political influence must play any part within ${ }^{73}$.

\section{Kyiv Recommendation}

The 2010 Kyiv Recommendation ${ }^{74}$ is particularly meaningful for a more precise and detailed definition of the role of the National Council of Judiciary, namely the "Judicial Councils"; but, unlike the previous European standards already mentioned, it suggested the creation of different independent bodies, not just one, "a good opinion is to establish different independent bodies competent for specific aspects of judicial administration" for the reason of "avoid excessive concentration of power in one judicial body and perceptions of corporatism" 75 .

Furthermore, an advanced innovation, is presented on the matter of the composition required; after having clarified in the same sense of the previous European instruments that "judge members shall be elected by their peers and represent the judiciary at large $" 76$, it introduced an exception to being a judge member specifically addressed to the appellate court judges and, as a result, it stated that

"Judicial Councils shall not be dominated by appellate court judges. Where the chairperson of a court is appointed to the Council, he or she must resign from his or her position as court chairperson".

\section{European Court of Human Rights' Criteria}

Although, the Venice Commission expressed a purely critical voice on the importance, on a more general ground, of the jurisprudence of the European Court of Human Rights, when it critically assessed that as regards to Article 6 of the European Convention on Human Rights, "the case-law of the Court sheds light on a number of important aspects of judicial independence but, by its very nature, does not approach the issue in a systematic way" ${ }^{\text {"77 }}$, the judicial experience of the Strasbourg Court remains a crucial legal parameter to reference

\footnotetext{
${ }^{70}$ European Association of Judges (1997).

${ }^{71}$ European Association of Judges (1997) at Principle 1.

${ }^{72}$ European Association of Judges (1997) at Principle 2.

${ }^{73}$ European Association of Judges (1997) at Principle 4.

${ }^{74}$ OSCE (2010).

${ }^{75}$ OSCE (2010) at Article 2.

${ }^{76}$ OSCE (2010) Article 7.

${ }^{77}$ Venice Commission (2010) at par. 13.
} 
and evaluate the conformity of European national legislations on all issues related to a potential jeopardy of the "fair trial" and, therefore, on the independence (and, impartiality) of the judicial bodies.

Furthermore and despite the fact that neither Article 6 nor any other provision of the European Convention on Human Rights requires that States must comply with a particular theoretical constitutional scheme, previously fixed or suggested, regarding the permissible limits of the powers' interaction and the respect of the separation of power, the question is always whether, in a given case, the requirements of the Convention are met or not ${ }^{78}$.

The European Court of Human Rights' case law ${ }^{79}$ when it is called to assess whether a judicial body can be labelled as an "independent" one referred, mainly, to four distinct criteria:

- The manner of appointment of the judicial members;

- The duration of the term of the judicial office;

- The existence of certain guarantees against outside pressures;

- Whether the body presents an appearance of independence.

In any case, it is worth noting, that the Court's reasoning, when dealing with the above mentioned parameters, involved necessarily a simultaneous assessment of the "impartiality", as a concrete and subsequent outcome; in fact, the following assessment by the Court involved a double approach, subjective, that it means to ascertain the personal conviction or concrete interest of the judge in a given case and, objective, consisting in determining potential doubts, fears or suspicions of the judges' behaviours and whether he offered guarantees sufficient to exclude any legitimate doubt in this respect ${ }^{80}$.

As clarified by the Court, in the vast majority of cases the focus was on the fulfilment of the objective test; however, there is no watertight division between the two approaches since the judge' conduct may not only prompt objectively held misgivings from the point of view of the external observer (objective test) but may also involves the issue of his or her personal conviction (subjective test) ${ }^{81}$.

\section{Manner of Appointment}

The first criteria involved the method followed in order to appoint the specific members of the judicial bodies and, in particular, the legal institution which should be in charge of the appointment, in other words, whether should be competent the legislative, executive or the judicial power itself.

On the merit, Article 6, par. 1 of the European Convention on Human Rights requires independence not only from the executive and the parties but also from

\footnotetext{
${ }^{78}$ Henryk Urban and Ryszard Urban v. Poland $\S 46$.

${ }^{79}$ Findlay v. the United Kingdom: Campbell and Fell v. United Kingdom $\S 78 ;$ Maktouf and Damjanovic v. Bosnia and Herzegovina § 49; Brudnicka and Others v. Poland $\S 38$.

${ }^{80}$ De Cubber v. Belgium $\$ 24$.

${ }^{81}$ Micallef v. Malta $\S 95 ;$ Kyprianou v. Cyprus $\S 119$.
} 
the legislator, namely the national Parliaments ${ }^{82}$; however the mere appointment of judges by Parliament cannot be seen to cast doubt on their independence ${ }^{83}$; similarly by the executive is permissible, if the judges are free from pressure or influence when carrying out their duties ${ }^{84}$.

For instance, in the case of Ninn-Hansen $v$. Denmark, the applicant complained against the manner of appointment of the lay judges, elected by the Parliament. However the Court declared that there were no reasonable doubts about their fairness of the adjudicatory role, indeed

"Although political sympathies may play part in the process of appointment of lay judges...the Court does not consider that this alone gives legitimate doubts as to their independence and impartiality...it is not established that they were appointed with a view to adjudicate this particular case or had declared political affiliations concerning the subject matter in issue. Nor has it been established that there existed other links between Parliament and the lay judges which could give rise to misgivings as to the lay judges' independence and impartiality ${ }^{85}$.,

Similarly, the Court declared in the case of Filippini contra Saint Marin, that the mere appointment by the legislator is not enough to declare the lack of independence of the judges, which requires a further step,

"A cet égard, leur seule élection par le Parlement ne saurait entacher l'indépendance des juges s'il ressort clairement de leur statut que, une fois désignés, ils ne reçoivent ni pressions ni instructions de la part du Parlement et exercent leurs fonctions en toute indépendance."

To establish a lack of independence in the manner of appointment, it is either necessary to show that the practice of appointment as a whole was unsatisfactory, or alternatively, that the establishment of the particular court or the appointment of the particular adjudicator gave rise to a risk of undue influence over the outcome of the case ${ }^{86}$; therefore, even though at stake is the independence of the judges, it will be necessary on the course of the overall legal reasoning a further assessment on the matter of impartiality in its outward form as the result of a lack of independence.

To sum up, although the assignment of a case to a particular judge or court and, therefore, the manner of their appointments falls normally within the margin of appreciation enjoyed by the domestic authorities in such matters, the Court must be satisfied that this was compatible with Article 6, par. 1, and, in particular, with its requirements of independence and impartiality ${ }^{87}$.

${ }^{82}$ Crociani et al $v$. Italy.

${ }^{83}$ Filippini contre Saint-Marin.

${ }^{84}$ See, Henryk Urban and Ryszard Urban v. Poland, Campbell and Fell v. United Kingdom, Maktouf and Damjanovic v. Bosnia and Herzegovina..

${ }^{85}$ Ninn-Hansen v. Denmark $§ 20$.

${ }^{86}$ Zand v. Austria $§ 78$.

${ }^{87}$ Moiseyev v. Russia $§ 176$. 


\section{Term of the Office}

The second requirement is the duration of the appointment; no particular term of office has been specified as necessary minimum; it is true that irremovability of judges by the executive during their term of office must, in general, be considered a corollary of their independence and thus included in the guarantees of Article 6, par. 1; however, the absence of a formal recognition of this irremovability in the law does not in itself imply lack of independence provided that it is recognised in fact and that the other necessary guarantees are present ${ }^{88}$.

"The term of office is admittedly relatively short but [...] there is a very understandable reason: the members are unpaid and it might well prove difficult to find individuals willing and suitable to undertake the onerous and important tasks involved if the period were longer" renewable four year appointment for a judge who was a member of a national security court was considered "questionable" by the Court in the case Incal v. Turkey "On the other hand, other aspects of these judges' status make it questionable [...] Lastly, their term of office as National Security Court is only four years and can be renewed ",90."

From another perspective, the Court, in the case of Maktouf and Damjanovic v. Bosnia and Herzegovina, considered the judicial mandate in line with the Article 6, par. 1, in a case questioning the presence of international judges appointed for a renewable two years' term on the bench of a court ruling on war crimes taking into account, on the whole, external and outward factors and, as a result, it concluded that

"Admittedly, their term of office was relatively short, but this is understandable given the provisional nature of the international presence at the State Court and the mechanics of international secondments ${ }^{91}$."

Interestingly, the Court in the case Gurov v. Moldova, where the applicant alleged a breach of Article 6 as the term of the office of a judge hearing a case was expired, provided an innovative interpretation of the term "established by law", which object is to ensure "that the judicial organisation in a democratic society does not depend on the discretion of the executive, but that it is regulated by law emanating from Parliament", moreover and, most importantly, the term covers not only the legal basis for the very existence of a "tribunal" but also the composition of the bench in each case ${ }^{92}$.

\footnotetext{
${ }^{88}$ See Campbell and Fell v. the United Kingdom, $\S 80$, Engel and Others, Series A no. 22, § 68, Henryk Urban and Ryszard Urban v. Poland, § 45, Maktouf and Damjanovic v. Bosnia and Herzegovina, § 49.

${ }^{89}$ Campbell and Fell v. the United Kingdom, $\S 80$.

${ }^{90}$ Incal v. Turkey§ 68.

${ }^{91}$ Maktouf and Damjanovic v. Bosnia and Herzegovina $\S 51$.

${ }^{92}$ Gurov v. Moldova $\S 34-35$; Posokhov v. Russia $\S 39$.
} 
Therefore, the Court concluded that there were no legal grounds for the involvement of the judge and, therefore, the case had not been heard by a tribunal established by law and, moreover, tacitly prolonging the term was in contradiction with the principle that the judicial organisation in a democratic society should not depend on the discretion of the executive ${ }^{93}$.

\section{Guarantees against Outside Pressures}

The third condition invokes the guarantee against an outward or outside pressure performed by the other State powers, the Court in Campbell and Fell $v$. the United Kingdom prescribed that the judicial members of a tribunal must, at a very minimum, be protected against a removal act passed by the legislate branch during their terms of office stating that

"The irrevocability of judges by the executive during their term of office must in general be considered as a corollary of their independence and thus included in the guarantees of Article 6 \$1. However, the absence of a formal recognition of this irremovability in the law does not in itself imply lack of independence provided that it is recognised in fact and that the other necessary guarantees are present."

This case looks particularly meaningful and sensitive as it deals directly and concurrently with two Court's criteria, respect of the term of the office and guarantee from an outside pressure, which appear to be in all of the cases concerning a pre-term removal prescribed by a legislative body an overlapping criteria put through the same Court's reasoning and legal analysis.

Furthermore, the European Court in the case of Sovtransavto Holding $v$. Ukraine $^{94}$, where the applicant lodged a complaint because of an assumed strong political pressure and the permanent monitoring of the legal proceedings by the Ukrainian authorities, including the President of Ukraine, found a clear violation of Article 6, par. 1 of the Convention, having regard to the interventions by the executive branch of the State in the judicial proceedings as, it declared that

"[...] the Ukrainian authorities acting at the highest level intervened in the proceedings on a number of occasions. Whatever the reasons advanced by the Government to justify such interventions, the Court considers that, in view of their content and the manner in which they were made, they were ipso facto incompatible with the notion of an "independent and impartial tribunal" within the meaning of Article 6, par. 1 of the Convention".

\footnotetext{
${ }^{93}$ Gurov v. Moldova $§ 37$.

${ }^{94}$ Sovtransavto Holding v. Ukraine $\S 40$.
} 
In a similar manner, and most interestingly, in Kinsky v. the Czech Republic ${ }^{95}$, the Court while declaring in its conclusion a violation of Article 6, par. 1 of the Convention, affirmed that

"the activities of certain politicians referred to by the applicant, be they verbal expressions to the media or other, aimed at creating a negative atmosphere around the legal actions of the applicant or constituting direct attempts to interfere in these proceedings, were unacceptable in a system based on the rule of law;"

therefore, it seems that even an indirect pressure performed by other State actors could amount to an illegitimate intervention sufficient to disturb, influence or shift the parameter of the judicial independence.

On a final note, it is not surprising that the Court when it is called to cope with the criteria of the guarantees against outside pressure acts in a very cautious and wary method, as it involves a very problematic argument, as it is the separation of powers, where no fixed models can be applied to national States and where the national sovereignty, expressed by the parliamentary will, still plays a role as primary leading actor in establishing national constitutional orders.

\section{Appearance of Independence}

The fourth needed requirement is the one concerning the appearance, which recalled the standpoint of an objective observer and, furthermore, the recognition of the judicial body by the people in terms of impartiality.

The Court reiterates that impartiality denotes the absence of prejudice or bias and its existence can be tested in various ways, the existence of impartiality for the purpose of Article 6, par. 1, must be determined according, first, to a "subjective test" where regard must be had to the personal behaviour of a particular judge, that is, whether the judge held any personal prejudice or bias in a given case and also according to an "objective test", that is to say by ascertaining whether the tribunal itself and, among other aspects, its composition, offered sufficient guarantees to exclude any legitimate doubt in respect of its impartiality. ${ }^{96}$

As stated by the Court, in Morice v. France, as to the objective test, it must be determined whether there are ascertainable facts which may raise doubts of impartiality and, the standpoint of the person concerned is important but not decisive, what is decisive is whether this fear can be held to be objectively justified $^{97}$.

An appearance of independence is crucial because as the Court clarified "what is at stake is the confidence which the courts in a democratic society must inspire in the public" $" 98$ and the appearances itself may be of a certain importance,

\footnotetext{
${ }^{95}$ Kinsky v. the Czech Republic $\$ 23$.

${ }^{96}$ Morice v. France $\S 73 ;$ Kyprianou v. Cyprus $\S 118$; Micallef v. Malta $\S 93$.

${ }^{97}$ Morice v. France, $\$ 76 ;$ Micallef v. Malta $\$ 96$.

${ }^{98}$ Incal v. Turkey $\$ 48 ;$ Fey v. Austria $§ 56 ;$ Morice v. France; $\$ 78$.
} 
"justice must not only be done, it must also be seen to be done"99; as factual examples, whether the public is reasonably entitled to entertain doubts as to the independence or impartiality of the tribunal ${ }^{100}$, whether there are legitimate grounds for fearing ${ }^{101}$, whether there are ascertainable facts that may raise doubts or whether such doubts can be objectively justified ${ }^{102}$, in so far, the objective test mostly concerns hierarchical or other links between the judge and other protagonists in the proceedings ${ }^{103}$.

In De Cubber v. Belgium, the Court focusing on the objective test because it said that "however, it is not possible for the Court to confine itself to a purely subjective test; account must also be taken of considerations relating to the functions exercised and to internal organisation (the objective approach)",104, referring to the Belgian Court of Cassation according to which any judge in respect of whom there is a legitimate reason to fear a lack of impartiality must withdraw because what is at risk is "the confidence which the courts in a democratic society must inspire in the public and above all, as far as criminal proceedings are concerned, in the accused ${ }^{, 105}$.

\section{The Polish Constitutional Tribunal}

The first judicial body exposed to the judicial reform plan initiated by the Polish ruling party, Law and Justice, was the Polish Constitutional Tribunal (Trybunal Konstytucyjny).

As a preliminary note, it is worth mentioning that Article 194 of the Polish Constitution explicitly states that "The Constitutional Tribunal shall be composed of 15 judges chosen individually by the Sejm for a term of office of 9 years from amongst persons distinguished by their knowledge of the law. No person may be chosen for more than one term of office".

The procedural changes that have occurred within the CT have been numerous and, among the many, a new quorum of eleven out of fifteen judges for certain decisions, the possibility for four judges to postpone any decision if they are not satisfied after an initial internal vote, the necessary presence of the prosecutor general for certain set of decisions, further disciplinary proceedings against the elected constitutional judges and a more wary publication of the CT judgments which currently relies on the formal approval of the Prime Minister and a broad and extensive list of hypothesis in which the publication of the judgements could be legitimately delayed ${ }^{106}$.

\footnotetext{
${ }^{99}$ Denisov v. Ukraine $§ 63$.

${ }^{100}$ Campbell and Fell $v$. the United Kingdom $\$ 20$.

${ }^{101}$ Langborger v. Sweden $\$ 34$; Procola v. Luxembourg $\$ 42 ;$ McGonnell v. the United Kingdom $\S 63$.

${ }^{102}$ Castillo Algar v. Spain $\S 45$.

${ }^{103}$ Micallef v. Malta, $\$ 97$.

${ }^{104}$ De Cubber v. Belgium $\S 26$.

${ }^{105}$ Ibid.

${ }^{106}$ See Sanders \& von Danwitz (2018).
} 
However, the most notable step taken by the Polish ruling party was a test of strength or showdown consisting in the replacement of five judges already sitting into the Constitutional Tribunal appointed after an endless legal diatribe based on several and twisted pre-facts ${ }^{107}$.

A few days before the 2015 parliamentary elections, on 8 October 2015 (by the end of the $7^{\text {th }}$ Term of Sejm), the lower Chamber of the Parliament, the old Sejm, elected five new judges, based on the amendment of the CT of 25 June 2015, instead of the appointment of just three judges, which as stated by both scholars and the Constitutional Court the election of those two extra judges was clearly improper and patently unconstitutional ${ }^{108}$.

On the matter, the Constitutional Tribunal in its notable ruling $\mathrm{K} \mathrm{35/15}$ declared that the election of the two extra judges was improper and, therefore, unconstitutional because was done by the VII Sejm, whose term ended on 12 November, while the tenure of the elected judges was to commence on the $2^{\text {nd }}$ and $8^{\text {th }}$ December respectively, the same day the nine-year tenure of the two former judges ended. Conversely, the appointment of the other three judges, whose tenure ended on 6 November, were proper and according to Constitution, as the tenure of the Sejm overlapped with the date of the ending of their mandate ${ }^{109}$; in other words, only the Sejm in office during which the mandate of the CT judges will expire is authorised to make the judicial appointment.

Afterwards, the Parliament, guided by the ruling party majority, adopted a resolution on 25 November $^{110}$, according to which all five judges had to be considered as irregular members and their election as null and void, consequently, on that ground on 2 December 2015 the new Sejm elected five new judges, reshaping the composition of the Constitutional Tribunal.

As stated by the Constitutional Tribunal in the $\mathrm{K} 34 / 15$ judgment, although, the former appointment of the two judges were, in fact, unconstitutional, the remaining mandate of the three other members were made according to the constitutional standards, therefore, the new government would have been allowed to appoint only two judges, rather than five of them in December 2015.

Furthermore, the other crucial legal argument for declaring the legitimacy of the new appointed judges was the one concerning the precise moment when they should assume their judicial office and, especially, the formality of the oath before the President of the Republic.

In short, the process of becoming a judge, in theory, ends with the election in the Sejm but in practice ends only after being sworn in by the President ${ }^{111}$ and on that basis the President, after the election of the five judges by the old Sejm,

\footnotetext{
${ }^{107}$ For a comprehensive and complete review of the constitutional crisis see Sadurski (2018).

${ }^{108}$ See Judgments of the Constitutional Tribunal of Poland: K 35/15, K 47/15, K 39/16, and U $8 / 15$.

${ }^{109}$ See Jankovic (2016)

${ }^{110}$ Official Gazette of the Republic of Poland 2015, item 1182-1186; see Sadursky (2018) at 21:

"The Constitution does not recognise the possibility of such a resolution annulling an earlier election of judges, a resolution which effectively adds a new, extra-constitutional, method of extinguishing the judicial term of office".

${ }^{111}$ Art. 5.5. and 5.6. of the Polish Constitutional Tribunal Act.
} 
refused to take the oath from them; however, on 2 December, the President took the oath by the new five judges immediately after their appointment.

The ruling of the K 34/15 judgment declared that the President has to take oath from elected judges immediately but the exclusive right to appoint judges rest in the power of the Sejm; as a result, the appointment ends with the election of Sejm and not with oath. Similarly, the K 35/15 judgment, declaring unconstitutional the amendment to the CT Act of 19 November 2015, which introduced a 30-day period during which the President should take the oath from elected judges, it would contradict the former judgment, K 34/15, as the President is obliged to take the oath immediately and introduced a role of co-participation, not prescribed by the constitutional scheme, in the election of the members of the Constitutional Tribunal.

Nonetheless and, quite predictably, the reshaped Constitutional Tribunal on

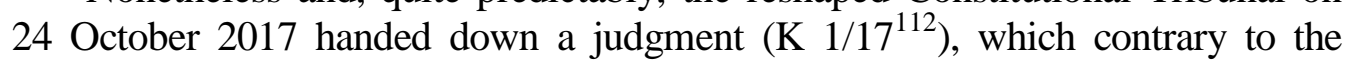
previous statement of the K 34/15 and, in contradiction with Art. 194 Constitution and its well-established interpretation, declared that the most important and constitutive element in order to held the office of judge, member of the Constitutional Tribunal, is the requisite of the oath before the President ${ }^{113}$.

\section{The National Council of Judiciary}

The Polish National Council of Judiciary (Krajowa Rada Sadownictwa or $K R S$ ) performs a crucial role within the Polish Constitutional boundaries as it was created in 1989 in the wake of the democratic transition as an authority to safeguard the independence of courts and judges ${ }^{114}$.

According to Article 186 of the Polish Constitution, the supreme judicial body acts as a guardian of the whole judicial system and, in this meaning, it "shall safeguard the independence of courts and judges"; its main task is to make judicial appointments by a motion which should be approved by the President of the Republic who formalised the proposed appointments ${ }^{115}$, then additional powers include submitting issues of constitutionality review to the Constitutional Tribunal, adopting a judicial code of ethics, expressing opinion on draft legal reform.

Concerning the KRS members, the composition is a mixed one which include all of the three powers of the State, Article 187 established in 25 the number of its members: 15 members from the judiciary branch, 4 members chosen by the Sejm among its deputies, 2 members chosen by the Senate among its members, the First President of the Supreme Court, the Minister of Justice, the President of the Supreme Administrative Court and one member appointed by the President of the Republic.

\footnotetext{
${ }^{112}$ See Judgment of the Constitutional Tribunal of Poland - K 1/17.

${ }^{113}$ Sadursky (2018) at 22.

${ }^{114}$ Mikuli (2017).

${ }^{115}$ Poland's Constitution, Art. 179.
} 
In particular, the Constitution text stated that " 15 judges chosen from amongst the judges of the Supreme Court, common courts, administrative courts and military courts" and, some scholars affirmed that, therefore, the selection is mostly conferred to the judiciary itself ${ }^{116}$, meanwhile, other commentators raised doubts on the legal text which it seems to not provide, explicitly, that judge members should be elected by the judiciary itself, even though it has always been understood that they are elected by the judiciary itself ${ }^{117}$.

Having clarified the Constitutional relevance of the National Council of Judiciary, the reform process which involved the judicial body went through a twostep process, an original draft proposal, then rejected by the President of the Republic which, later on, became with some adjustments a definitive legal reform.

According to the first draft proposal, adopted by the Parliament on 12 July 2017 (Act of 23 January 2017), the National Council of Judiciary would have been divided into two different chambers, one of judicial composition, meanwhile, the other composed of political members and, a decision for become binding should have gained the consensus from both chambers. Moreover, other innovations include, in the case of the application of multiple candidates for a vacant position, the Council should have presents at least two names to the attention to the President, who could choose one of them discretionally, the power to appoint judicial members entirely entrusted by the low chamber (Sejm), to terminate, immediately, the mandate of the sitting judges through a specific transitional provisions.

However, the President of the Republic expressed concerns on the amendment referring to the immediate termination of the judicial mandate, especially in relation to the Article 187, par. 3, of the Constitution, which established that "The term of office of those chosen as members of the National Council of the Judiciary shall be 4 years" and, therefore, vetoed the initial proposal.

The definitive version on the new Council of Judiciary voted by the Sejm on 8 December 2017 and Senate 15 December 2017, signed by the President on 20 December 2017, came into force on the date of 15 January 2018, which confirms the election of the 15 judicial members by the lower chamber, Sejm, performed through a quite twisted procedure.

First of all, the candidates may be proposed by groups of citizens (2000) or 25 judges, then on that basis each of the parliamentary caucuses could nominate up to 9 candidates and, later on, the parliamentary committee will select 15 candidates to be presented to the Sejm; the low chamber, in the first round, will elect the appropriate candidates by a $3 / 5$ majority and, if the quorum is not achieved, the Sejm seems to be able to elect the candidates by a simple majority procedure or even less.

More precisely, in the second round candidates are elected "by a roll call", each Parliamentary member has one vote and may vote only one candidate, candidates who have received the highest number of votes shall be deemed to

\footnotetext{
${ }^{116}$ Sanders \& von Danwitz (2018) at 776.

${ }^{117}$ Sadursky (2018) at 143.
} 
have been elected and each Parliamentary member may vote for or against, or abstain; afterwards, in case of tie, a candidate who received fewer votes against will be elected ${ }^{118}$.

However, Parliament is not obliged to select candidates with sufficient support in the judiciary and may choose candidates who have only minimal support amongst their colleagues and, for this reason, Venice Commission emphasised the procedure as "regrettable" because the judicial community has insufficient weight in the NCJ election ${ }^{119}$.

Furthermore, a pre-term removal of the sitting judges, despite the 4 years' term guaranteed by the Constitution, indeed, the Article 6 of the Act provides for an early termination of the term of office of all sitting judicial members supported by the judgment of the Constitutional Tribunal of 20 June $2017^{120}$, where the Court declared that the term of the office of the members should be seen as a collective term, as a body, and not as an individual term of office.

In this regard, the Venice Commission after showing all of its scepticisms about the notion of "joint term of office", stated that even assuming the latter as politically legitimate, the Polish aim could have been achieved differently, "the currently serving judicial members may remain in their position until the original term of their mandate expires, while new members could be elected for a shorter period, ensuring that at some point in future the whole composition of the NCJ will be renewed simultaneously. This solution will not only respect the security of tenure but also better ensure the institutional continuity of the body" ${ }^{\prime 21}$.

\section{The Law on the Supreme Courts}

The new Polish Law on the Supreme Court ("the Law on the Supreme Court"), entered into force by 3 April 2018, prescribes several legal innovations: a new retirement age for all the sitting judges, a new method for appointing the Chief Justice of the Supreme Court, an increase of the total number of the sitting judges, the creation of two new chambers, one for hearing disciplinary cases and another for extraordinary appeals and, lastly, a new judicial review procedure called the "extraordinary complaint"122.

Evidently, the new age limit drawn up by the reform is the main target of severe criticisms displayed by scholars ${ }^{123}$ and institutional European actors; indeed, the Law on the Supreme Court, prescribed in section 37, a lowering of the current retirement age applies to all judges, including those appointed before the entry in force of the law, pushing it down to 65 years; thus, as it

\footnotetext{
${ }^{118}$ Venice Commission (2017) at par. 21.

${ }^{119}$ Venice Commission (2017) at par. 27.

${ }^{120}$ Judgment of the Constitutional Tribunal of Poland: K 5/17.

${ }^{121}$ Venice Commission (2017) at par. 30, which recalls Venice Commission (1998) at para 20, 21.

${ }^{122}$ See, Sadursky (2018) at 146.

${ }^{123}$ Sadursky (2018) at 145; Sanders \& van Danwitz (2018) at 35.
} 
patently appears the most concerning argument of the new reform is the prevision of the so-called "early retirement age".

Nonetheless, the judges affected by the retirement age requisite could continue to hold their judicial office under three certain specific conditions:

- a submission of a statement indicating the desire to continue to perform his duties;

- a certificate stating a good health conditions;

- a formal approval by the President of the Republic

The third condition, the mandatory approval by the President of the Republic, seems to be the most debatable and controversial prerequisite, for the reason that the President itself seems not bound by any legal criteria and, furthermore, his final decision is not subject to a further judicial review.

Venice Commission expressed its concerns when it stated that

In the first place, there is no apparent rationale determining the office of which judges might be extended; it appears to be at the discretion of the President of Poland. This will give the President excessive influence over those judges who are approaching the retirement age ${ }^{124}$

and, concerning the substantial absence of judicial remedies, "Under the Draft Act, Polish judges exposed to early retirement would not have any judicial remedy at their disposal. Given the recent developments in the case-law of the $E C t H R$, absence of judicial remedies in this situation appears problematic"125.

In particular, Venice Commission referred its concerns taking into account the meaning expressed in the pivotal case Baka v. Hungary ${ }^{126}$, concerning the right of access to further judicial remedies for civil servants in case of prematurely dismissal from the judicial office, where the European Court of Human Rights declared the existence of a violation of the right of fair trial as enshrined in Article 6, $\S 1$ of the Convention ${ }^{127}$.

\section{The Hungarian Precedent}

In 2011 Hungary adopted a similar legislation of the one propelled by Poland regarding the shortening of the mandatory retirement age for judges from 70 to 62 years within a short transitional period, afterwards, the European Commission in January 2012 launched an infringement proceedings and referred the case to the Court of Justice of $\mathrm{EU}^{128}$.

\footnotetext{
${ }^{124}$ Venice Commission (2017) at par. 51.

${ }^{125}$ Ibid, $\$ 50$.

${ }^{126}$ Baka v. Hungary.

${ }^{127}$ Baka v. Hungary $\S 196$.

${ }^{128}$ ECJ Case C-286/12, Commission v. Hungary; however, on 20 November 2013, the Commission closed the infringement procedure because "the new law adopted by the Hungarian Parliament on 11 March 2013 lowers the retirement age for judges, prosecutors and notaries to 65 over a period of 10 years, rather than lowering it to 62 over one year, as before [...] The new law also
} 
Reducing the age of retirement, as a general concept, and effectively shortening the term of office during the term may be considered unconstitutional, as was found by both the Hungarian Constitutional Court ${ }^{129}$ and the Court of Justice of the $\mathrm{EU}^{130}$; moreover, the Venice Commission, relied upon the Hungarian Constitutional Court judgment, declared that "It trusts that the Hungarian authorities will respect this judgment and ensure its implementation, i.e. re-instate the former judges to their previous position" $"$.

Indeed, the Hungarian Constitutional Court declared unconstitutional the retirement age provisions for violation of judicial independence on formal and substantive grounds; from the formal requirement, the reform should have determined the length of judicial service and the precise retirement age, being not enough clear the reference to the general retirement age, meanwhile from the substantive ground, the new law resulted in the removal of judges within a short period of three months has to be seen as a clear risk to the judicial safeguards and, therefore, contrary to the constitutional provisions ${ }^{132}$.

Likewise, in the case C- 286/12, the Court of Justice of the EU based its decision on the proper application of the antidiscrimination directive ${ }^{133}$, stating that even if the "standardisation of retirement age" or a "balanced age structure" could amount to a legitimate employment policy objective, the measures put forward by the Hungarian government were not necessary nor proportionate to achieve this aim ${ }^{134}$.

Finally, the Hungarian reform was contested on the international level before the European Court of Human Rights in the well-known case Baka v. Hungary, lodged by the former President of the Supreme Court against the premature termination of his mandate which should constitute a violation of Article $6, \S 1$ of the European Convention, namely the right to a fair trial, for the reason that no judicial remedy was technically possible in order to react to the alleged violation; indeed, the Strasbourg Court confirmed that the reform enacted at a constitutional level was not subject to any form of judicial review even by the Hungarian Constitutional Court and, as a result, found a breach of the right to access to a court for a judicial remedy and, therefore, a jeopardy of the right of a fair trial.

However and quite surprisingly, as already pointed out from several scholar works, the international institutions dealing with the pith of the Hungarian case, Court of Justice of the EU and European Court of Human Rights limited themselves to rather technical questions and they evaded more precise and detailed remarks on the authentic background of the case (judicial independence) and,

\footnotetext{
provides for the right for all judges and prosecutors who had been forced to retire before to be reinstated in their posts, with no need to bring a case to court. Moreover, they will be compensated for remuneration lost during the period they were not working".

${ }^{129}$ Judgment no. 33/2012 (VII. 17) of 16 July 2012.

${ }^{130}$ ECJ Case C-286/12, Commission v. Hungary.

${ }^{131}$ Venice Commission (2017) at par. 75.

${ }^{132}$ Baka v. Hungary $\S 45$.

${ }^{133}$ European Union, Council of the European Union, Council Directive 2000/78/EC (2000).

${ }^{134}$ See Vincze (2014) at 207.
} 
therefore, surrounded in a very cautious and wary way the judicial independence $\operatorname{argument}^{135}$.

\section{Conclusion}

The judicial reform plan carried out, right after the parliamentary election of 2015, by the new Polish parliament with a strong majoritarian component guided by the Law and Justice party raises several problematic and intricate assessments at European level taking into account the consolidated European standards on the matter.

The political and legal diatribe which involved the composition of the Polish Constitutional Tribunal appears to be particular sensitive with regard to the proper interpretation of the crucial principle of separation of power where the legislative and executive branches must abstain from an overdue influence upon the judiciary especially when it comes to deal with the selection process; the warning enclosed in the introductory remarks by the Judges' Charter about the European integration process, the increasing role of the legislative and executive powers and the future risks of the erosion of checks and balances sounds now greater than ever, particularly within the group of fragile democracies.

Furthermore, the new composition of the Supreme Tribunal and its proactive role in enforcing the political and legal legitimacy of the parliamentarian stances, as for instance the U-turn on the K 34/15 ruling, takes into the spotlight several suspicions from the European Court of Human Rights perspective and the criteria developed by its well-established jurisprudence, particularly on the manner of appointment, the guarantees against an outside pressure and the appearance of independence of the judicial body.

Next in order, the new legal reform that reshaped the Polish National Council of Judiciary, a judicial body in charge of the protection of the independence of courts and judges, which establishes a pre-term removal for all the sitting judges along with the increased power of the Parliament in the appointment process seems to clash with all the existing European standards on the matter.

First of all, as previously clarified by the 1994 Council of Europe Recommendation the principle of irremovability must assume a decisive weight according to which the judges' mandate should have guaranteed till the expiry of the term of the office; then, it is an established and unanimous standard the one which requires that a majoritarian component or, at least one half, of the judges members of the National Council of Judiciary should be elected by their peers, even though, the "democratic legitimacy" element of the Parliament should play a role on the election of the residual judicial members.

Lastly, the new law on the Supreme Courts which prescribed, similarly to the former Hungarian reform, an early retirement age for all the sitting Supreme Courts' judges, could pose a serious risk of consistency with the principle of irremovability, corollary of the judicial independence, for several order of reasons

${ }^{135}$ Sanders \& von Danwitz (2018) at 785; Vincze (2014) at 212, when it stated that "The judgment of the ECJ did not even mention the world judicial independence". 
and, primarily, in the exceptional cases of a judge who wish to continue to held its office on the requisite of the formal approval by the President of the Republic.

Indeed, the President's decision seems not bound by any legal criteria and there is no chance of judicial review for the retired judges that could potentially lead to a short-circuit before the European Court of Human Rights which should be called to pronounce to several cases and to replicate ad infinitum the legal reasoning previously expressed in Baka v. Hungary, where the lack of judicial remedies in case of an early judicial dismissal guided the Court to declared the violation of the Article $6, \S 1$ of the Convention.

\section{References}

Cappelletti, M. (1983). 'Who Watches the Watchmen? A Comparative Study on Judicial Responsibility', American Journal of Comparative Law, 31(1):1-62.

Vincze, A. (2014), 'Judicial Independence and its guarantees beyond the Nation State - Some recent Hungarian experience', Journal of the Indian Law Institute, 56(2):202-215.

Jankovic, S. (2016) 'Polish Democracy Under Threat? An Issue of Mere Politics or A Real Danger?' in Baltic Journal of Law \& Politics, Vol. 9 (1), October 17, 2016; DOI: https://doi.org/10.1515/bjlp-2016-0003

Mikuli, P. (2017). 'An Explicit Constitutional Change by Means of an Ordinary Statute? On a Bill Concerning the Reform of the National Council of the Judiciary in Poland', iconnectblog.com, February 23, 2017, at http://www. iconnectblog.com/2017/02/an-explicit-constitutional-change-by-means-of-anordinary-statute-on-a-bill-concerning-the-reform-of-the-national-council-of-thejudiciary-in-poland/

Sadurski, W. (2018). 'How Democracy Dies (in Poland): A Case Study of AntiConstitutional Populist Backsliding”, Revista Forumul Judecatorilor, 104, January 17, 2018.

Sanders, A. \& L. von Danwitz (2018) 'Selecting Judges in Poland and Germany: Challenges to the Rule of Law in Europe and Propositions for a New Approach to Judicial Legitimacy' in German Law Journal 19(4) 769-816.

Shetreet, Sh. (2014). 'Judicial Independence, Liberty, Democracy and International Economy', Chapter 2 in The Culture of Judicial Independence. Leiden: Brill.

Storme, M. (2014). 'Independence of the Judiciary: The European Perspective', Chapter 4 in The Culture of Judicial Independence. Leiden: Brill.

Vincze, A. (2014), "Judicial Independence and its guarantees beyond the Nation State - Some recent Hungarian experience", Journal of the Indian Law Institute, 56(2):202-215.

\section{International Instruments}

Consultative Council of European Judges CCJE (2010)3. Magna Carta of Judges, Strasbourg 17.11.2010.

Consultative Council of European Judges CCJE (2001). Opinion No. 1 of the Consultative Council of European Judges for the attention of the Committee of 
Ministers of the Council of Europe on Standards concerning the Independence of the Judiciary and the Irremovability of Judges, Strasbourg, 23.11.2001.

Consultative Council of European Judges (CCJE) (2003). Opinion No. 5 of the Consultative Council of European Judges to the attention of the Committee of Ministers of the Council of Europe on the Law and Practice of Judicial Appointments, Strasbourg, 27.11.2003.

Consultative Council of European Judges (CCJE) (2005). Opinion No. 7 of the Consultative Council of European Judges (CCJE) to the attention of the Committee of Ministers of the Council of Europe on "Justice and Society", Strasbourg, 25.11.2005.

Consultative Council of European Judges (CCJE) (2007). Opinion No. 10 of the Consultative Council of European Judges (CCJE) to the attention of the Committee of Ministers of the Council of Europe on the Council for the Judiciary at the service of society, Strasbourg, 23.11.2007.

Consultative Council of European Judges (CCJE) (2014). Opinion No. 17 on the evaluation of Judges' work, the quality of justice and respect for judicial independence, Strasbourg, 24.10.2014.

Consultative Council of European Judges (CCJE) (2015). Opinion No. 18 on the position of the judiciary and its relation with the other powers of state in a modern democracy, London, 16.10.2015.

Council of Europe (1950). European Convention for the Protection of Human Rights and Fundamental Freedoms (Rome, 4.11.1950).

Council of Europe (1994). Independence, Efficiency and Role of Judges, Recommendation No. R (94) 12 adopted by the Committee of Ministers on 13.10.1994 at the 518th meeting of the Ministers' Deputies.

Council of Europe (1998). European Charter on the statute for judges and Explanatory Memorandum, DAJ/DOC (98) 23, Strasbourg 8-10.11.1998.

Council of Europe (2010). Judges: independence, efficiency and responsibilities, Recommendation CM/Rec (2010)12 adopted by the Committee of Ministers of the Council of Europe on 17.11.2010 and explanatory memorandum.

Council of the European Union (2000). Council Directive 2000/78/EC of 27 November 2000 establishing a general framework for equal treatment in employment and occupation, OJ L 303 (2.12.2000).

European Association of Judges (1997). (EAJ). Judges' Charter in Europe, 4.11.1997.

European Commission (2014). A new EU Framework to strengthen the Rule of Law, COM (2014) 0158 final (11.3.2014).

European Commission (2016). College Orientation Debate on recent developments in Poland and the Rule of Law Framework: Questions \& Answers (13.1.2016).

European Commission (2018). The 2018 EU Justice Scoreboard (May 27, 2018);

European Court of Human Rights. Guide on Article 6 of the European Convention on Human Rights, 31.8.2018.

European Court of Human Rights. Judicial Seminar 2018. The Authority of the Judiciary, 26.1.2018.

European Network of Council for the Judiciary (ENCJ). Council for the Judiciary Report 2010-2011 and Development of Minimum Judicial Standards. European Union (2012). Charter of Fundamental Rights of the European Union, OJ C 326 (October 26, 2012).

European Union: Council of the European Union, Council Directive 2000/78/EC of 27 November 2000 establishing a general framework for equal treatment in employment and occupation, OJ L 303, 02/12/2000 (27.11.2000). 
International Association of Judges. The Universal Charter of the Judge, Taiwan, 17.11.1999.

OSCE (2010). Office for Democratic Institutions and Human Rights and Max Planck Minerva Research Group on Judicial Independence. Kyiv Recommendations on judicial independence in Eastern Europe, South Caucasus and Central Asia, Kyiv 23-25.6.2010.

Poland (2018). The Chancellery of the Prime Minister. White Paper on the Reform of the Polish Judiciary, 7.3.2018.

The Judicial Integrity Group (JIG) (2002). The Bangalore Principles of Judicial Conduct, E/CN.4/2003/65, The Hague (25-26.11.2002)).

United Nations (1985). Basic Principles on the Independence of the Judiciary, adopted by the Seventh United Nations Congress on the Prevention of Crime and the Treatment of Offenders held at Milan from 26 August to 6 September 1985 and endorsed by General Assembly resolutions 40/32 of 29 November 1985 and 40/146 of 13.12.1985.

United Nations (1995). UN Commission on Human Rights. Independence and impartiality of the judiciary, jurors and assessors and the independence of lawyers., E/CN.4/RES/1995/36, 3.3.1995.

Venice Commission (1998). Council of Europe. European Commission for Democracy Through Law. Opinion on Recent Amendments to the Law on Major Constitutional provisions of the Republic of Albania, CDL-INF (1998), Strasbourg, 17.4.1998.

Venice Commission (2002). Council of Europe. European Commission for Democracy Through Law. Opinion on the Draft Law on Judicial Power and Corresponding Constitutional Amendments of Latvia, CDL-AD (2002)026-e, Strasbourg, 29.10.2002.

Venice Commission (2007). Council of Europe. European Commission for Democracy Through Law. Judicial Appointments, CDL-AD (2007)028, Venice, 22.6.2007.

Venice Commission (2008). Council of Europe. European Commission for Democracy Through Law. European Standards on the Independence of the Judiciary, A Systematic Overview, CDL-JD (2008)002, Study No. 494/2008, Strasbourg, 3.10.2008.

Venice Commission (2010). Council of Europe. European Commission for Democracy Through Law. Report on the Independence of the Judicial System, Part I: The independence of judges, CDL-AD (2010)004, Strasbourg, 16.3.2010.

Venice Commission (2017). Council of Europe. European Commission for Democracy Through Law. Opinion on the Draft Act amending the Act on the National Council of the Judiciary, on the Draft Act amending the Act on the Supreme Court, proposed by the President of Poland, and on the Act on the Organisation of Ordinary Courts, CDL-AD (2017)031, Strasbourg, 11.12.2017.

\section{Legislation}

Poland: Constitution of the Republic of Poland, 2 April, 1997.

Poland: Constitutional Tribunal Act, 17 October 1997.

Poland: Law on the Supreme Court, 3 April, 2018. 


\section{Cases}

\section{European Court of Human Rights (ECtHR)}

Baka v Hungary [GC], no. 20261/12, ECtHR 23 June 2016.

Brudnicka and Others $v$ Poland, no. 54723/00, ECHR 2005-II.

Campbell and Fell $v$ the United Kingdom, Series A no. 80.7878/77, [1984] ECHR 8

Castillo Algar v. Spain, 28 October 1998, Reports of Judgments and Decisions ECHR 1998-VIII.

Crociani et al v. Italy, ECtHR 18 December 1980, nos. 8603/79, 8722/79, 8723/79, $8729 / 79$.

De Cubber v. Belgium, ECtHR 26 October 1984, Series A no. 86.

Denisov v. Ukraine [GC], no. 76639/11, ECtHR 25 September 2018.

Engel and Others v. the Netherlands, ECtHR 8 June 1976, Series A no. 22.

Filippini contre Saint-Marin, no. 10526/02, ECHR 2003.

Findlay v. the United Kingdom, 25 February 1997, Reports of Judgments and Decisions 1997-I.Gurgurov v. Moldova, ECHR no. 7045/08, 16 June 2009.

Henryk Urban and Ryszard Urban v. Poland, ECHR no. 23614/08, 30 November 2010.

Incal v. Turkey, 9 June 1998, ECtHR Reports of Judgments and Decisions 1998-IV.

Kinsky'v. the Czech Republic, App. 42856/06, ECtHR 9 February 2012.

Kyprianou v. Cyprus [GC], no. 73797/01, ECHR 2005-XIII.

Langborger v. Sweden, 22 June 1989, ECtHR Series A no. 155.

Maktouf and Damjanović v. Bosnia and Herzegovina [GC], nos. 2312/08 and 34179/08, ECHR 2013 (extracts).

McGonnell v. the United Kingdom, no. 28488/95, ECHR 2000-II.

Micallef v. Malta [GC], no. 17056/06, ECHR 2009.

Moiseyev v. Russia, no. 62936/00, ECHR 9 October 2008.

Morice v. France [GC], no. 29369/10, ECHR 2015.

Ninn-Hansen v. Denmark (dec.), no. 28972/95, ECHR 1999-V.

Posokhov v. Russia, no. 63486/00, ECHR 2003-IV.

Previti v. Italy (dec), no. 45291/06, ECHR 2009.

Procola v. Luxembourg, ECHR 28 September 1995, Series A no. 326.

Sovtransavto Holding v. Ukraine, no. 48553/99, ECHR 2002-VII.;

Zand v. Austria, ECtHR no. 7360/76, Decision of 16 May 1977.

\section{European Court of Justice (ECJ)}

ECJ, order of the Vice-President of the Court in Commission v. Poland C-619/18R (EU:C:2018:852, October 19, 2018).

ECJ, judgment of the Court in Commission v. Hungary C-286/12 (EU:C:2012:687, November 6, 2012).

ECJ, judgment of the Court (Second Chamber) in Fuchs and Köhler v. Land Hessen C-160/10 (EU:C:2011:508).

ECJ, judgment of the Court (Grand Chamber) in Félix Palacios de la Villa v. Cortefiel Servicios SA C-411/05 (EU:C:2007:604). 
Trybunal Konstytucyjny (Constitutional Tribunal of Poland)

Judgment of 9 December 2015, Ref. No. K 35/15, 186/11/A/2015.

Judgment of 9 March 2016, Ref. No. K 47/15,/s/k-4715.

Judgment of 11 August 2016, Ref. No. K 39/16.

Judgment of 7 January 2016, Ref. No. U 8/15, OTK ZU no. 1/A/2016.

Judgment of 24 October 2017, Ref. No. K 1/17, OTK ZU no. A/2017.

Judgment of 11 May 2017, Ref. No. K 5/17, OTK ZU, no. A/2017.

Magyarország Alkotmánybírósága (Constitutional Court of Hungary)

Judgment no. 33/2012 (VII. 17) of 16 July 2012. 
